ANALELE UNIVERSITĂTIII DIN BUCUREȘTI - SERIA DREPT

\title{
Continuarea judecăţii sau restituirea cauzei la procuror? Despre consecinţele procedurale naţionale ale deciziei CJUE din cauza C-282/20 ZX
}

Conf. univ. dr. Andrei Zarafiu

Giulia Șologon, Master Științe Penale Facultatea de Drept, Universitatea din București

Rezumat: La data de 21 octombrie 2021, Curtea de Justiție a Uniunii Europene a pronunțat hotărârea în cauza ZX și Spetsializirana prokuratura (Parchetul Specializat, Bugaria) cererea nr. C-282/20, prin care a stabilit că art. 6 alin. (3) din Directiva 2012/13/UE a Parlamentului European și a Consiliului din 22 mai 2012 privind dreptul la informare în cadrul procedurilor penale și art. 47 din Carta drepturilor fundamentale a Uniunii Europene trebuie interpretate în sensul că se opun unei legislații naționale care nu reglementează o cale procedurală aptă a permite ulterior ședinței de cameră preliminară, într-o cauză penală, remedierea neclarităților și a lacunelor din conținutul rechizitoriului, neregularități ce aduc atingere dreptului persoanei acuzate de a i se comunica informații detaliate cu privire la acuzare.

Prezentul articol realizează o analiză a domeniului de aplicare al hotărârii pronunțate în cauza ZX și a remediilor procesuale reglementate în Codul de procedură penală român aplicabile în cazul modificării elementelor de fapt și de drept ale acuzației în materie penală formulate impotriva inculpatului.

În aplicarea jurisprudenței CJUE, art. 6 alin. (3) din Directiva 2012/13 și art. 47 CDFUE impun statelor membre să reglementeze o legislație care să permită remedierea în cursul judecății a neclarităților și lacunelor din conținutul rechizitoriului care aduc atingere dreptului persoanei acuzate de a i se comunica informații detaliate cu privire la acuzare. Totodată, dreptul național trebuie interpretat conform dreptului Uniunii Europene, în sensul că judecătorul trebuie să apeleze la toate mijloacele procesuale reglementate de lege pentru a se asigura că inculpatul primește informații detaliate cu privire la temeiul de fapt și de drept al acuzației, astfel încât să-și poată exercita dreptul la apărare.

Numai în ipoteza în care legislația națională prevede impedimente în activitatea judecătorului pentru a furniza respectivele informații ori pentru a înlătura neclarități și lacune ale rechizitoriului de natură a compromite dreptul inculpatului în înțelegerea elementelor esențiale ale acuzației, acesta are posibilitatea de a lăsa neaplicate respectivele norme pentru a se asigura că inculpatul primește informațiile necesare privind temeiul de fapt și de drept al acuzației necesare formulării apărărilor.

În cadrul normativ actual, absența unor dispoziții exprese care să stabilească la nivel procedural o modalitate de remediere a neregularităților actului de sesizare creează premisa 
adoptării unor soluții exclusiv pe cale judiciară, fără a avea un fundament normativ. În doctrină, au fost conturate două remedii, primul presupunând o intervenție directă a procurorului asupra actelor procesuale și procedurale prin care să fie adusă la îndeplinire dispoziția judecătorului de cameră preliminară ori a instanței de excludere fizică a probelor nelegale sau neloiale, fără a opera o dezînvestire a instanței.

$\mathrm{Cel}$ de-al doilea remediu presupune o restituire a cauzei fie la parchet, fie chiar la procuror, după distincțiile evocate pe parcursul prezentului studiu. Unde ar trebui însă să se dispună restituirea cauzei? La parchet sau la procuror? Nuanța este importantă pentru că presupune diferențe în ceea ce privește mecanismul procedural prin care se realizează reluarea urmăririi penale în actualul sistem procesual penal.

În final, apreciem că remedierea neregularității actului de sesizare prin restituirea cauzei și reactivarea funcției judiciare de urmărire penală este preferabilă intervenției directe a procurorului în faza de judecată, reprezentantul Ministerului Public având posibilitatea ca, în ipoteza în care dorește să iș̦i mențină dispoziția de trimitere în judecată, să poată reface actele procesuale și să emită un nou rechizitoriu regulamentar întocmit.

Pentru argumentele amplu dezvoltate în cuprinsul prezentului studiu, dispoziția instanței de judecată ar trebui să fie de restituire a cauzei la procuror și nu la parchet, întrucât parcurgerea filtrului procedural pe care îl presupune restituirea la parchet și care implică abilitarea exclusivă a conducătorului parchetului de a evalua în ce măsură se impune reluarea urmăririi penale (potrivit dispozițiilor art. 334 C.proc.pen.) este, în acest caz, superfluă. Luând în considerare natura incidentelor care provoacă imposibilitatea continuării judecății în ipotezele analizate în prezentul articol, aplicarea directă a jurisprudenței CJUE ar trebui să determine o reluare obligatorie a urmăririi penale circumscrise nevoii de înlocuire a actelor compromise prin care s-a configurat succesiv acuzația formulată în materie penală.

Conchizând asupra celor evocate anterior, menționăm că remediile propuse prin hotărârea CJUE pronunțată în cauza ZX ar trebui să opereze doar în contextul limitat apt a le justifica existența. Acestea nu trebuie să devină mecanisme de eludare o obligației procedurale a instanței de judecată de a soluționa cauza. Astfel, reiterăm faptul că, dacă anumite incidente ivite în cursul judecății, precum schimbarea încadrării juridice dată faptei sau excluderea probelor determinante, nu vizează aspectul extern al acuzației, ci reprezintă chiar carențe interne, strâns legate de temeinicia acesteia, instanța este obligată să îşi realizeze în mod complet funcția activată prin sesizare și învestire, urmând a pronunța o soluție de achitare, întrucât probele în acuzare nu întrunesc standardul minim necesar angajării răspunderii penale prevăzut de art. 103 alin. (2) C.proc.pen., dincolo de orice dubiu rezonabil. În aceste condiții, remediile prezentate, indiferent de ordinea de preferință stabilită de către interpret, devin incidente în măsura în care există neclarități sau ambiguități ale acuzației de natură a împiedica exercitarea adecvată a funcției de judecată, nu și atunci când acuzația nu este sprijinită de probe clare, apte a dovedi dincolo de orice dubiu rezonabil vinovăția inculpatului.

Cuvinte cheie: neregularitatea actului de sesizare, rechizitoriu, restituirea cauzei la parchet, restituire cauzei la procuror, schimbarea încadrării juridice, excluderea probelor, dreptul la informare al acuzatului. 


\section{Continuing the trial or returning the case to the prosecutor? On the national procedural consequences of the CJEU decision in the C-282/20 ZX case}

Abstract: On October 21, 2021, the European Court of Justice ruled in ZX and Spetsializirana prokuratura (Specialized Prosecutor's Office, Bulgaria), application no. C 282/20, by which it established art. 6 para. (3) of Directive 2012/13 / EU of the European Parliament and of the Council of 22 May 2012 on the right to information in criminal proceedings and the Article 47 of the Charter of Fundamental Rights of the European Union must be interpreted as precluding national legislation which does not provide, after closing the preliminary hearing, for a procedure remedy for the ambiguities and gaps in the content of the indictment, irregularities, which affect the right of the accused person to be provided with detailed information on the indictment.

This specific article analyzes the meaningful purpose of the judgment in ZX and the procedural remedies regulated in the Romanian Code of Criminal Procedure applicable to changes in the factual and legal elements of the indictment.

In applying the jurisprudence of the ECJ, art. 6 para. (3) of Directive 2012/13 and art. 47 The EU CDF requires Member States to regulate legislation that allows for the legal recourse in court of any ambiguities and gaps in the content of the indictment that affect the right of the accused person to be provided with detailed information on the accusation. At the same time, national law must be interpreted in accordance with European Union law, in the sense that the judge must resort to all procedural means regulated by law in order to ensure that the defendant receives detailed information on the factual and legal grounds of the accusation and may apply properly for the right of defense.

Only if national law entails impediments in the activity of the judge to provide such information or to remove any ambiguities and gaps in the indictment, which may compromise the defendant's right to understand the essential elements of the prosecution, he may ensure that the defendant receives the right information on the factual and legal basis of the charge necessary to formulate the defense.

In the current regulatory framework, the absence of express provisions to establish on the procedural level a way to remedy the irregularities of the indictment conceives the premise of adopting solutions exclusively in court, without having a normative basis. In the doctrine, two remedies were outlined, the first involving a directly intervention of the prosecutor on procedural acts, which helps in enforcing the order of the judge of the preliminary hearing or the court of physical exclusion of illegal or unfair evidence, without operating a disinvestment of the court.

The second remedy involves a restitution of the case either to the prosecutor's office or even to the prosecutor, according to the distinctions evoked during the present study. But where should the restitution be ordered? At the prosecutor's office or at the prosecutor? The nuance is important because it implies differences in the procedural mechanism by which the resumption of criminal prosecution is carried out in the current criminal procedural system.

Finally, we consider that remedying the irregularity of the indictment by restituting the case and reactivating the judicial function of criminal prosecution is preferable to the direct intervention of the prosecutor in the trial phase, the representative of the Public Ministry having the possibility to maintain the possibility to redo the procedural documents and to issue a new regulatory indictment. 
For the arguments extensively developed in this study, the court's order should be a return to the case to the prosecutor and not to the prosecutor's office, as the procedural filter of restitution to the prosecutor's office involves the exclusive power of the chief prosecutor to assess the extent to which it is necessary to resume the criminal investigation (according to the provisions of art. 334 CPC) is, in this case, superfluous. Being given the nature of the incidents that makes impossible for the trial to, in the cases discussed in this article, the direct application of the jurisprudence of the ECJ should lead to a mandatory resumption of the criminal prosecution limited to the need to replace compromised acts that successively set up criminal charges.

In conclusion, we note that the remedies proposed by the ECJ judgment in ZX should only operate in the limited context capable of justifying their existence. These should not become mechanisms for circumventing a procedural obligation of the court to resolve the case. Thus, we reiterate that if certain incidents arising during the trial, such as the change of the legal classification of the deed or the exclusion of decisive evidence, do not concern the external aspect of the accusation, but represent internal shortcomings closely related to its validity, the court is obliged to fully perform its function activated by notification and investment, following to rule on an acquittal, as the evidence in the accusation does not meet the minimum standard necessary to engage in criminal liability provided by art. 103 para. (2) CPC, beyond any reasonable doubt. Under these conditions, the remedies presented, regardless of the order of preference established by the interpreter, become incidental insofar as there are ambiguities in the accusation that could impede the proper exercise of the judicial function, not when the accusation is not supported by evidence, capable of proving beyond any reasonable doubt the guilt of the defendant.

Key words: irregularity of the act of referral, indictment, restitution of the case to the prosecutor's office, restitution of the case to the prosecutor, change of legal classification, exclusion of evidence, right to information of the accuse.

\section{HOTĂRÂREA CJUE ÎN CAUZA ZX ȘI SPETSIALIZIRANA PROKURATURA, CEREREA NR. C-282/20}

La data de 21 octombrie 2021, Curtea de Justiție a Uniunii Europene a pronunțat hotărârea în cauza ZX și Spetsializirana prokuratura (Parchetul Specializat, Bugaria) cererea nr. C-282/20, prin care a stabilit că art. 6 alin. (3) din Directiva 2012/13/UE a Parlamentului European și a Consiliului din 22 mai 2012 privind dreptul la informare în cadrul procedurilor penale și art. 47 din Carta drepturilor fundamentale a Uniunii Europene trebuie interpretate în sensul că se opun unei legislații naționale care nu reglementează o cale procedurală aptă a permite ulterior ședinței de cameră preliminară, într-o cauză penală, remedierea neclarităților și a lacunelor din conținutul rechizitoriului, neregularități ce aduc atingere dreptului persoanei acuzate de a i se comunica informații detaliate cu privire la acuzare.

În speță, Curtea a reținut că inculpatul ZX a fost trimis în judecată pentru falsificare de monedă, acesta punând în circulație 88 de bancnote de 200 de euro despre care știa că sunt contrafăcute. Legea procesual penală bulgară, potrivit căreia a fost judecat inculpatul ZX, reglementează instituția ședinței preliminare, în cadrul căreia instanței îi revine competența de a verifica, printre altele, legalitatea actelor de urmărire penală și regularitatea actului de sesizare. În cadrul ședinței preliminare, inculpatul ZX a invocat 
neregularitatea rechizitoriului, din perspectiva formală, însă critica sa a fost respinsă de către instanță.

Ulterior finalizării cercetării judecătorești, pentru a intra în dezbateri, instanța a constatat neclarități și lacune ale rechizitoriului, sub aspectul elementelor esențiale care descriau acuzația (preliminar, durata în care persoana acuzată a deținut cele 88 de bancnote contrafăcute nu ar fi fost indicată cu precizie; mai mult, rechizitoriul ar fi descris în mod incomplet caracteristicile juridice ale faptei incriminate și, în sfârșit, ar fi existat o eroare în indicarea dispozițiilor de drept penal bulgar a căror încălcare este invocată). Deși, în ședința publică din 12 iunie 2020, procurorul și-a exprimat intenția de a remedia neregularitățile actului de sesizare, instanța a constatat că dispozițiile legii procesual penale bulgare [art. 287 alin. (1)] reglementau posibilitatea restituirii cauzei la parchet numai în situația modificării substanțiale a temeiului de fapt sau de drept al acuzației, în urma aprecierii probelor administrate în cursul cercetării judecătorești, dacă, potrivit noii acuzații, competența de judecare a infracțiunii revine unei instanțe superioare, unei instanțe specializate ori unei instanțe militare ${ }^{1}$. Având în vedere că neregularitățile actului de sesizare presupuneau exclusiv clarificarea acuzației formulate la momentul trimiterii în judecată, iar nu formularea unei noi acuzații, instanța a stabilit că în cauză sunt incidente dispozițiile art. 248 alin. (3) din Codul de procedură penală bulgar, potrivit cărora neregularitatea rechizitoriului poate fi analizată numai în ședința preliminară, iar, ulterior debutului judecății în primă instanță, orice încălcare a normelor fundamentale de procedură care a determinat restrângerea drepturilor procedurale ale inculpatului, ale persoanei vătămate sau ale succesorilor în drepturi ale acestora în cursul urmăririi penale nu mai poate fi pusă în discuție și nu mai poate determina suspendarea judecății, respectiv restituirea cauzei la procuror pentru refacerea actului de sesizare.

Analizând standardul minim de protecție a dreptului la apărare, impus prin Directiva 2012/13/UE a Parlamentului European și a Consiliului din 22 mai 2012 privind dreptul la informare în cadrul procedurilor penale și prin art. 47 din Carta drepturilor fundamentale a Uniunii Europene, Curtea a stabilit că informațiile referitoare la acuzare transmise apărării pot face obiectul unor modificări ulterioare, în special în ceea ce privește încadrarea juridică a faptelor pentru care s-a dispus trimiterea în judecată. Asemenea modificări trebuie însă comunicate persoanei acuzate sau avocatului său la un moment în care aceștia dispun încă de posibilitatea de a reacționa în mod eficient, înainte de faza deliberării, pentru a garanta caracterul echitabil al procesului penal.

Din ansamblul jurisprudenței CJUE reiese că drepturile care decurg din art. 6 alin. (3) din Directiva 2012/13 trebuie asigurate pe tot parcursul procesului penal, inclusiv după finalizarea ședința preliminară într-o cauză penală. Or, o legislație care nu reglementează o cale procedurală care să permită remedierea viciilor din rechizitoriu după finalizarea ședinței preliminare împiedică persoana acuzată să cunoască în mod suficient de detaliat acuzațiile care i se aduc, ceea ce este de natură să împiedice exercitarea efectivă a dreptului

\footnotetext{
${ }^{1}$ Art. 287 alin. (1) (modificat prin Legea nr. 32/2010, în vigoare din 28.05.2010) Procurorul întocmește un nou act de acuzare în cazul în care constată, în cursul cercetării judecătorești, că există temeiuri a modifica substanțial descrierea situației de fapt din actul de acuzare sau pentru a aplica o lege care sancționează infracțiuni mai grave.

(2) (modificat prin Legea nr. 61/2011, în vigoare de la 01.01.2012) Instanța încetează judecata și trimite cauza procurorului respectiv, atunci când noua infracțiune atrage competența unei instanțe superioare, a unei instanțe penale specializate sau a unei instanțe militare. (traducerea autorilor)
} 
la apărare, încălcând astfel standardul prevăzut în art. 6 alin. (3) din Directiva 2012/13 și art. 47 din Carta drepturilor fundamentale a UE.

Sub aspectul obligațiilor ce le revin organelor judiciare când constată neregularități ale actului de sesizare, Curtea a reținut că într-o situație în care procesul penal nu a fost finalizat, exercitarea drepturilor procesuale prevăzute în art. 6 alin. (3) din Directiva 2012/13 poate fi asigurată atât în situația în care instanța, în faza judecății, are competența funcțională de a remedia neregularitățile actului de sesizare, cât și în cea în care procurorului căruia îi va fi trimisă cauza să poată dispune remedierea respectivelor neregularități, asigurând respectarea dreptului la apărare. Oricare ar fi momentul în care inculpatului i se vor furniza informațiile precise de natură a-i configura acuzația în materie penală conform art. 6 alin. (3) din Directiva 2012/13, organele judiciare trebuie să asigure inculpatului și avocatului său, cu respectarea principiului contradictorialității și a egalității armelor un termen suficient pentru a lua cunoștință de aceste informații și să li se ofere posibilitatea de a pregăti în mod eficient apărarea, de a-și prezenta observațiile și, dacă este cazul, de a formula orice cerere în probațiune pentru a dovedi netemeinicia acuzației în materie penală formulate.

În speță, instanța de trimitere a arătat că mecanismul prevăzut în art. 287 din Codul de procedură penală bulgar i-ar permite restituirea cauzei la parchet pentru ca procurorul să refacă actul de sesizare, astfel încât să elimine lacunele și neclaritățile în descrierea situației de fapt, iar inculpatul ar avea un timp suficient pentru a-și pregăti apărarea în raport de aceste modificări, inclusiv prin formularea unor cereri de administrare a unor probe noi. $\mathrm{Cu}$ toate acestea, mecanismul prevăzut de art. 287 din Codul de procedură penală bulgar nu putea fi aplicat din perspectiva instanței de trimitere, având în vedere existența interdicției prevăzută în art. 248 alin. (3) din Codul de procedură penală bulgar, care interzicea instanțelor de prim grad, de apel și de recurs să constate încălcarea normelor fundamentale de procedură care putea fi îndreptată și care a determinat restrângerea drepturilor procesuale ale inculpatului dacă această problemă nu a fost tranșată definitiv în procedura ședinței preliminare.

Fără a oferi o soluție tranșantă în speță cu privire la conflictul dintre normele prevăzute în art. 287 și 248 alin. (3) din Codul de procedură penală bulgar, CJUE a arătat că revine instanței de trimitere sarcina de a efectua o interpretare conformă a Codului de procedură penală cu dispozițiile dreptului UE, astfel încât să permită procurorului remedierea neregularităților din conținutul rechizitoriului în faza judecății, protejând în același timp, în mod activ și real dreptul la apărare al persoanei acuzate. Numai în ipoteza în care apreciază că o interpretare conformă nu este posibilă, instanța de trimitere este obligată să lase neaplicată orice normă care exclude posibilitatea remedierii în faza de judecată a neregularității rechizitoriului, constând în insuficienta descriere a situației de fapt, putând dispune chiar suspendarea judecății și restituirea cauzei la parchet în vederea refacerii actului de sesizare.

\section{DOMENIUL DE APLICARE AL HOTĂRÂRII CJUE PRONUNTTATĂ LA 21 OCTOMBRIE 2021 ÎN CAUZA ZX ȘI SPETSIALIZIRANA PROKURATURA}

Pentru înțelegerea și aplicarea principiilor conținute în jurisprudența CJUE, trebuie realizată o analiză completă atât a domeniului de aplicare al hotărârii pronunțate în cauza 
ZX, cât și a remediilor procesuale reglementate în Codul de procedură penală român aplicabile în cazul modificării elementelor de fapt și de drept ale acuzației în materie penală formulate împotriva inculpatului.

În primul rând, hotărârea CJUE vine în completarea unei jurisprudențe în materia dreptului la informare al persoanelor acuzate prevăzute în Directiva 2012/13. Prin Hotărârea Marii Camere pronunțată la 05.06.2018 în cauza C-612/15 privind pe Nikolai Kolev, Milko Hristog și Stefan Kostadinov (denumită în continuare Hotărârea Kolev) s-a stabilit că art. 6 alin. (3) din Directiva 2012/13 impune ca inculpații să primească informații detaliate cu privire la acuzare și după depunerea în instanță a rechizitoriului, ca act de sesizare, dar înainte de începerea examinării pe fond a cauzei și deschiderea dezbaterilor ori chiar ulterior deschiderii dezbaterilor, dar înainte de etapa deliberării, atunci când informațiile astfel comunicate fac obiectul unor modificări ulterioare, cu condiția ca instanța să ia toate măsurile necesare pentru a garanta respectarea dreptului la apărare și garantarea caracterului echitabil al procedurii.

Totodată, art. 7 alin. (3) din Directivă trebuie interpretat în sensul că, revine instanței naționale sarcina de a asigura apărării posibilitatea efectivă de a avea acces la materialul cauzei și după sesizarea instanței prin rechizitoriu, dar înainte de examinarea pe fond a acuzației ori chiar de închiderea dezbaterilor atunci când probele noi sunt administrate exclusiv în faza judecății. Prin această hotărâre, CJUE a clarificat domeniul de aplicare a art. 6 alin. (3) din Directivă, în sensul că informații detaliate, privitoare la acuzare, includ atât stabilirea încadrării juridice, cât și descrierea faptei.

De asemenea, Curtea a stabilit momentul maxim până la care trebuie comunicate respectivele informații, în concret, până la deschiderea dezbaterilor pe fondul cauzei, indiferent dacă judecata are loc în baza procedurii obișnuite ori a unei proceduri abreviate, bazată pe recunoașterea învinuirii. Dacă respectivele elemente noi intervin în stadiul dezbaterilor, obligația instanței de a comunica inculpatului informații detaliate despre acuzare nu este înlăturată, ci doar termenul este devansat, respectiv, până la închiderea dezbaterilor și înainte de debutul stadiului deliberării. Cu alte cuvinte, instanța europeană impune ca instanța să nu rețină cauza în vederea deliberării, fără ca inculpatul să cunoască cu exactitate care este fapta și încadrarea juridică asupra cărora va purta deliberarea. Nu în ultimul rând, CJUE a stabilit că orice modificare a descrierii în fapt sau în drept a acuzației trebuie să fie însoțită de garanția informării inculpatului și a posibilității acestuia de a formula cereri de probe în vederea apărării și a dovedirii nevinovăției.

Ulterior, la 12 februarie 2020, CJUE a pronunțat o nouă hotărâre în același proces aflat pe rolul instanțelor bulgare (Cauza C-704/18) prin care a circumstanțiat concluziile anterioare, arătând că art. 6 alin. (3) și art. (7) alin. (3) din Directiva 2012/13 nu se opun unei norme de drept procesual penal care obligă prima instanță să se conformeze unei hotărâri pronunțate de o instanță superioară într-o cale de atac, prin care cauza este trimisă spre rejudecare cu obligația de a dispune restituirea cauzei la parchet în vederea remedierii neregularităților rechizitoriului.

Curtea a reiterat principiile evocate anterior în materia aplicării art. 6 din Directiva 2012/13. Astfel, cauza ZX se limitează la protejarea dreptului prevăzut de art. 6 alin. (3) din Directiva 2012/13 ce reglementează obligația statelor membre de a se asigura că cel târziu la prezentarea fondului acuzării în instanță (la debutul stadiului dezbaterilor - s.n.) se oferă informații detaliate cu privire la acuzare, inclusiv natura și încadrarea juridică a infracțiunii, precum și forma de participație a persoanei acuzate. Totodată, potrivit alin. (4) al aceluiași 
articol, statele membre se asigură că persoanele suspectate sau inculpate sunt informate cu promptitudine cu privire la orice modificare a informațiilor oferite în conformitate cu prezentul articol, acolo unde este necesar pentru a garanta caracterul echitabil al procedurilor.

În aceste condiții, apreciem că domeniul de aplicare al hotărârii CJUE trebuie circumscris ipotezelor în care neregularitatea rechizitoriului este determinată de insuficienta descriere a situației de fapt, greșita stabilire a încadrării juridice ori intervenția în cursul judecății a unor elemente care să determine schimbarea încadrării juridice. Având în vedere temeiul care a dus la pronunțarea hotărârii analizate, apreciem că această jurisprudență nu poate fi extinsă și la alte situații care determină neregularitatea actului de sesizare ori la unele ipoteze în care instanța ar constata în faza judecății eventuala nelegalitate a unor acte de urmărire penală ce nu au consecințe directe asupra descrierii situației de fapt reținută în rechizitoriu. Per a contrario, când nelegalitatea unor acte de urmărire penală, în special când efectul acesteia a condus la excluderea de probe, determină schimbarea unor împrejurări de fapt în raport de care procurorul și-a configurat acuzația prin rechizitoriu, dispozițiile art. 6 alin. (3) din Directiva 2012/13 sunt aplicabile, iar instanțele de judecată au obligația ca, în adoptarea remediilor prevăzute în Codul de procedură penală, să aibă în vedere inclusiv jurisprudența CJUE prevăzută în hotărârea ZX.

În al doilea rând, Codul de procedură penală român prevede în cuprinsul dispozițiilor art. 386 garanții procesuale suficiente pentru a asigura aplicarea efectivă a drepturilor prevăzute în art. 6 alin. (3) și (4) din Directiva 2012/13. Mai mult, prin Decizia nr. 250/2019, Curtea Constituțională a României a stabilit că dispozițiile art. 386 alin. (1) Cod procedură penală sunt constituționale numai în măsura în care schimbarea încadrării juridice dată faptei pentru care s-a dispus trimiterea în judecată se dispune printr-o hotărâre care nu soluționează fondul cauzei. În atare situație, Curtea Constituțională a statuat că protejarea efectivă a dreptului la apărare a inculpatului impune instanțelor judecătorești să dispună schimbarea încadrării juridice cel târziu în stadiul dezbaterilor pentru a permite comunicarea către inculpat a informațiilor esențiale privind temeiul de drept al acuzației în materie penală formulate, asigurând astfel timpul și înlesnirile necesare pregătirii unei apărări efective, precum și posibilitatea inculpatului de a solicita completarea sau, după caz, reluarea cercetării judecătorești pentru a propune noi probe prin care să dovedească neîntrunirea elementelor constitutive ale infracțiunii în noua configurație juridică.

Pe cale de consecință, jurisprudența CJUE poate crea premisele unui mecanism prin care dreptul la apărare al inculpatului să fie protejat în mod corespunzător exclusiv în ipoteza existenței unor neclarități și lacune în stabilirea temeiului de fapt al acuzației, iar nu a celui de drept. Normele de drept procesual penal român, prin procedura schimbării încadrării juridice prevăzută de art. 386, conțin garanții corespunzătoare în cazul existenței unor neclarități sau modificări ale temeiului de drept al acuzației în materie penală, asigurând sub acest aspect o protecție efectivă a garanțiilor procesuale prevăzute în art. 6 paragraful (3) și (4) din Directiva 2012/13. 


\section{GARANTIIILE PENTRU RESPECTAREA DREPTULUI LA APĂRARE ÎN PROCEDURA CAMEREI PRELIMINARE}

Posibilitatea restituirii cauzei la procuror pentru refacerea actului de sesizare ori a urmăririi penale nu este străină dreptului procesual penal român, fiind o soluție adoptată pentru prima dată în art. $310^{1}$ din Codul de procedură penală al Republicii Populare Române (republicat în 1948), introdus prin Decretul nr. 506/1953. În baza respectivei norme, "În tot cursul judecaţii, instanţa, prin încheiere, restituie cauza procurorului, în vederea completării sau refacerii actelor de urmărire penală, dacă din administrarea probelor sau din dezbateri rezultă ca urmărirea penală nu este completă şi ca, în faţa instanţei, nu s-ar putea face completarea ei cu asigurarea stabilirii adevărului material şi a rapidităţii judecării cauzei.

În cazul arătat în alineatul precedent, instanţa indică ce fapte şi împrejurări urmează a fi stabilite şi prin ce anume mijloace de probă sau ce acte de urmărire penală trebuie efectuate sau refăcute.

În cazul cînd se constată că nu au fost respectate dispoziţiile privitoare la trimiterea în judecată, instanţa, prin încheiere, reia examînarea cauzei în sedinţă pregătitoare, procedînd potrivit celor prevăzute în Capitolul III, Titlul III din Cartea II."

Aceste dispoziții au suferit unele modificări, iar în Codul de procedură penală din 1968 au fost reglementate art. 332 privind restituirea cauzei pentru refacerea urmăririi penale și art. 333 privind restituirea cauzei pentru completarea urmăririi penale ${ }^{2}$. Cele două texte de lege și-au dovedit ineficiența în special după aderarea României la Convenția Europeană a Drepturilor Omului (1994), constituind două mijloace care prelungeau nejustificat durata procesului penal și în unele cazuri presupuneau reluarea urmăririi penale doar pentru ca instanța să nu pronunțe o soluție de achitare.

În filosofia Codului de procedură penală de la 1968, verificarea legalității actului de sesizare și a urmăririi penale se realiza în două etape. Potrivit art. 300, „Instanţa este datoare să verifice din oficiu, la prima înfăţişare, regularitatea actului de sesizare. În cazul în care se constată că sesizarea nu este făcută potrivit legii, iar neregularitatea nu poate fi înlăturată de îndată şi nici prin acordarea unui termen în acest scop, dosarul se restituie organului care a întocmit actul de sesizare, în vederea refacerii acestuia". Ulterior, în temeiul art. 332: „Când se constată, înainte de terminarea cercetării judecătoreşti, că în cauza supusă judecăţii s-a efectuat cercetare penală de un alt organ decât cel competent, instanţa se desesizează şi restituie cauza procurorului, care procedează potrivit art. 268 alin. 1. Cauza nu se restituie atunci când constatarea are loc după începerea dezbaterilor sau când instanţa, în urma cercetării judecătoreşti, schimbă încadrarea juridică a faptei într-o altă infracţiune pentru care cercetarea penală ar fi revenit altui organ de cercetare.

Instanţa se desesizează şi restituie cauza procurorului pentru refacerea urmăririi penale în cazul nerespectării dispoziţiilor privitoare la competenţa după materie sau după calitatea persoanei, sesizarea instanţei, prezenţa învinuitului sau a inculpatului şi asistarea acestuia de către apărător. (...)".

Deși la o primă vedere posibilitatea restituirii cauzei către procuror în faza de judecată era aptă a asigura verificarea standardului de legalitate a urmăririi penale în tot cursul judecății în primă instanță și în căile de atac, aplicarea concretă a acestei proceduri a dus la multiple încălcări ale termenului rezonabil de soluționare a cauzelor penale, Curtea

\footnotetext{
${ }^{2}$ Abrogat prin art. I pct. 158 din Legea 356/2006
} 
Europeană a Drepturilor Omului reținând că restituirea cauzei la procuror constituia o măsură mult mai gravă pentru drepturile inculpatului deoarece, din culpa organelor judiciare, care au încălcat normele de procedură, cauza reajungea într-un stadiu incipient, deși trecuse de cele mai multe ori prin toate etapele fazei judecății. ${ }^{3}$

Odată cu adoptarea Noului Cod de procedură penală, legiuitorul a înlocuit procedura prevăzută la art. 300 și art. 332 din reglementarea anterioară, cu instituția camerei preliminare, urmărind a crea o etapă procesuală în cadrul fazei judecății atribuită în competența funcțională a unui organ judiciar distinct, judecătorul de cameră preliminară, al cărei scop a fost acela de a verifica anterior debutului judecății în primă instanță regularitatea actului de sesizare și legalitatea actelor de urmărire penală, inclusiv a celor în materia administrării probelor.

Noua reglementare corespunde mult mai bine garanției soluționării cauzei într-un termen rezonabil, având în vedere că problemele privind regularitatea actului de sesizare și legalitatea actelor de urmărire penală sunt tranșate definitiv anterior etapei judecății în primă instanță, fără a mai exista posibilitatea ca instanța de judecată în prim grad sau în apel să dispună restituirea cauzei la parchet. Corelativ procedurii de cameră preliminară, legiuitorul a modificat și regimul juridic al nulităților actelor de urmărire penală, stabilind în cuprinsul art. 281 alin. (4) și art. 282 alin. (4) Cod procedură penală că nulitatea relativă a actelor de urmărire penală poate fi invocată până la închiderea procedurii de cameră preliminară în fața judecătorului de la instanța sesizată cu rechizitoriu, iar nulitatea absolută poate fi invocată până la închiderea procedurii de cameră preliminară în contestația prevăzută de art. 347 Cod procedură penală.

Chiar dacă ulterior, prin deciziile Curții Constituționale nr. 802/2017 și 88/2019 a fost instituită posibilitatea invocării unor cauze de nulitate absolută a actelor de urmărire penală în toată faza judecății, domeniul de aplicare a respectivelor decizii cuprinde exclusiv actele de urmărire penală prin care au fost administrate probe, astfel că punerea în aplicare a acestora poate determina eventual excluderea de probe, iar nu situații ce ar impune constatarea neregularității actului de sesizare și restituirea cauzei la parchet în vederea refacerii acestuia.

Astfel, apreciem că în noua configurație a Codului de procedură penală, instituția camerei preliminare asigură o ocrotire corespunzătoare a dreptului la apărare al inculpatului, asigurând deopotrivă posibilitatea acestuia de a invoca nelegalitatea oricărui act de urmărire penală în fața unui judecător și respectarea termenului rezonabil de soluționare a cauzelor penale. Chiar dacă procedura de cameră preliminară a suferit modificări, odată cu pronunțarea multiplelor decizii ale Curții Constituționale, existând inclusiv posibilitatea efectuării cercetării judecătorești în această etapă, crearea unui cadru în care problemele de legalitate ale urmăririi penale să fie discutate definitiv anterior judecății în primă instanță asigură un standard de protecție mai ridicat dreptului la apărare al inculpatului.

În acest context, imposibilitatea restituirii cauzei la parchet ulterior închiderii procedurii camerei preliminare este de natură a asigura continuitatea fazei judecății, fără ca inculpatul să suporte consecințele defavorabile ale conduitei nelegale a organelor judiciare, respectiv regresul cauzei penale în faza de urmărire penală după parcurgerea parțială sau integrală a celor două etape ale judecății. În atare situație, apreciem că hotărârea Curții de

\footnotetext{
${ }^{3}$ C. Bălan, Termenul rezonabil în procesul penal român, Editura Hamangiu, București 2021, pag. 69
} 
Justiție a Uniunii Europene trebuie interpretată astfel încât să mențină standardul de protecție a dreptului la apărare al inculpatului, inclusiv sub aspectul termenului rezonabil de soluționare a cauzelor penale, iar eventuala posibilitate de restituire a cauzei la procuror în etapa judecății în primă instanță sau în apel să fie o măsură excepțională în ipoteza în care normele ce reglementează instituția camerei preliminare nu sunt apte a garanta dreptul la informare al inculpatului cu privire la temeiurile de fapt ale acuzației în materie penală formulate împotriva sa în conformitate cu dispozițiile art. 6 alin. (3) și (4) din Directiva 2012/13.

\section{APLICAREA ÎN DREPTUL PROCESUAL PENAL ROMÂN A HOTĂRÂRII CJUE PRONUNȚATĂ LA 21 OCTOMBRIE 2021 ÎN CAUZA ZX ȘI SPETSIALIZIRANA PROKURATURA}

a. Așa cum am arătat anterior, art. 6 alin. (3) din Directiva 2012/13 și art. 47 CDFUE impun statelor membre să reglementeze o legislație care să permită remedierea în cursul judecății a neclarităților și lacunelor din conținutul rechizitoriului care aduc atingere dreptului persoanei acuzate de a i se comunica informații detaliate cu privire la acuzare. Totodată, dreptul național trebuie interpretat conform dreptului Uniunii Europene, în sensul că judecătorul trebuie să apeleze la toate mijloacele procesuale reglementate de lege pentru a se asigura că inculpatul primește informații detaliate cu privire la temeiul de fapt și de drept al acuzației, astfel încât să-și poată exercita dreptul la apărare.

Numai în ipoteza în care legislația națională prevede impedimente în activitatea judecătorului pentru a furniza respectivele informații ori pentru a înlătura neclarități și lacune ale rechizitoriului de natură a compromite dreptul inculpatului în înțelegerea elementelor esențiale ale acuzației, acesta are posibilitatea de a lăsa neaplicate respectivele norme pentru a se asigura că inculpatul primește informațiile necesare privind temeiul de fapt și de drept al acuzației necesare formulării apărărilor.

b. Cu caracter preliminar, apreciem că trebuie realizată o distincție între lacunele și neclaritățile rechizitoriului în descrierea situației de fapt care pot determina constatarea neregularității acestuia și cele care relevă deficiențe probatorii majore ale acuzației, conducând la pronunțarea unei soluții de achitare în baza principiului in dubio pro reo. În acest sens, neregularitatea actului de sesizare poate interveni dacă împrejurările de fapt în baza cărora este configurată acuzația sunt redate într-o formă în care inculpatul nu poate determina activitățile infracționale pentru care a fost trimis în judecată și se află în imposibilitatea de a formula cererile probatorii corespunzătoare unei apărări efective. în egală măsură, absenţa unor repere factuale esenţiale pentru determinarea dimensiunii materiale a acuzaţiei formulate se manifestă ca un impediment major în declanşarea funcţiei de judecată ce trebuie luat în considerare din oficiu de judecătorul de cameră preliminară, independent de poziţia procesuală a acuzatului.

Astfel, câtă vreme finalitatea procedurală primară a actului de sesizare - învestirea instanţei şi fixarea unui cadru procesual clar şi previzibil pentru desfăşurarea judecăţii - nu poate fi asigurată ca urmare a carenţelor formale sau de conţinut ale acuzaţiei, judecătorul de cameră preliminară este obligat să refuze declanşarea funcţiei de judecată. Prin urmare, premisa dispoziţiei judiciare de refuz al începerii judecăţii este determinată de nevoia satisfacerii nu doar a unei exigenţe de interes particular - garantarea dreptului la apărare în 
multiplele sale componente, ci şi a uneia de interes public, evocată de dispoziţiile art. 1 alin.(2) C.p.p. - asigurarea exercitării eficiente a atribuţiilor organelor judiciare.

Pe de altă parte, dacă fundamentul acuzației este într-atât de echivoc încât din descrierea situației de fapt nu reiese cu claritate însăşi existenţa infracţiunii pentru care s-a dispus trimiterea în judecată sau întrunirea elementelor sale constitutive, aceasta va constitui o chestiune de probațiune, și nu de neregularitate a actului de sesizare. Într-o atare situație, judecata trebuie să înceapă, întrucât nu există lacune în descrierea faptei, ci în probele pe care se sprijină acuzația, neexistând niciun impediment pentru ca instanţa, în urma exercitării funcţiei sale judiciare, să dispună soluţia achitării în cazul în care nu poate fi atins standardul probatoriu (beyond any reasonable doubt) necesar declarării vinovăţiei în sens procesual, ce implică o triplă constatare: a existenţei materiale ori juridice a faptei ce face obiectul acuzaţiei, a caracterului său infracţional şi a săvârşirii sale de persoana trimisă în judecată.

Pe acest palier, trebuie evocată diferenţa de abordare structurală dintre sistemul procesual penal naţional şi cel italian, în pofida evidentei raportări, ca sursă de inspiraţie normativă, a redactorilor actualului Cod de procedură penală român la etapa procedurală similară preparatorie judecăţii şi denumită I'udienza preliminare.

Astfel, în sistemul italian ${ }^{4}$, cum finalitatea procedurală a acestei faze predecizionale este de de a verifica natura idonee a investigaţiilor preliminare (finalizate prin solicitarea de începere a judecăţii) de a susţine acuzaţia în faza judecăţii, acţionând ca un veritabil filtru destinat a împiedica judecăţile inutile ori superflue, şi cum probele nu pot fi câştigate, prin administrare, decât în condiţii de oralitate şi contradictorialitate în faţa judecătorului natural (de scaun) - deci în faza judecăţii - , judecătorul de l'udienza preliminare poate refuza începerea judecăţii chiar şi în ipoteza în care nu identifică suficiente surse probatorii achiziţionate în etapa investigaţiilor preliminare apte să susţină acuzaţia în timpul judecăţii. Nu va fi permisă aşadar declanşarea fazei centrale a procesului de tip adversial care fie să permită compensarea carenţelor probatorii ale fazei investigative, fie să confirme inaptitudinea unei acuzaţii de a angaja răspunderea penală câtă vreme această inaptitudine era evidentă din faza predecizională.

c. În reglementarea procedurii camerei preliminare, inculpatul beneficiază de o serie de garanții pentru a pune în discuție și obține înlăturarea oricăror neclarități privind temeiurile de fapt și de drept ale acuzației. În baza art. 344 Cod procedură penală, inculpatul poate invoca în camera preliminară cereri și excepții privind neregularitatea actului de sesizare, inclusiv în ceea ce privește modalitatea de descriere a situației de fapt. Mai mult, judecătorul de cameră preliminară este obligat în baza art. 346 alin. (3) lit. a) să restituie cauza la parchet dacă neregularitățile rechizitoriului nu au fost remediate de către procuror în termenul prevăzut la art. 345 alin. (3), iar respectivele neregularități atrag imposibilitatea stabilirii obiectului și a limitelor judecății.

În aceste condiții, judecătorul de cameră preliminară de la instanța sesizată cu rechizitoriu are obligația de a dispune începerea judecății numai dacă stabilește că modalitatea de descriere a faptei cuprinsă în rechizitoriu este suficientă pentru ca inculpatul

\footnotetext{
${ }^{4}$ A se vedea în acest sens Giulio Garuti, în Procedura penale, sesta edizione, lucrare colectivă, G.Giapichelli Editore, Torino, 2018, p.477-510; Luca della Ragione, Manuale di Diritto Processuale Penale, V edizione, Nel Diritto Editore, 2019, p.517-552; Faustino Izzo, Manuale di Diritto Processuale Penale, XXI edizione, Edizioni giuridiche Simone, Napoli, 2013, p.353-372.
} 
să cunoască faptele pentru care a fost trimis în judecată, precum și celelalte limite în care va avea loc judecata în primă instanță. Dacă inculpatul apreciază că neregularitățile privind descrierea situației de fapt din rechizitoriu atrag în continuare imposibilitatea stabilirii obiectului și a limitelor judecății, poate a formula contestație împotriva încheierii prin care judecătorul de cameră preliminară a început judecata.

Acest ultim aspect marchează o diferență între procedura penală română și cea bulgară care a fost analizată de Curtea de Justiție a Uniunii Europene prin hotărârea pronunțată în cauza ZX. Potrivit art. 248 alin. (5) pct. 4 și art. 252 din Codul de procedură penală bulgar, după finalizarea ședinței preliminare, instanța va acorda primul termen de judecată cu citarea părților, dacă rechizitoriul este regulamentar întocmit ori acesta cuprinde numai erori materiale care nu-i afectează substanța.

În sistemul procesual-penal român, hotărârea prin care judecătorul de cameră preliminară de la instanța sesizată prin rechizitoriu dispune începerea judecății, stabilind obiectul și limitele acesteia, este supusă controlului instanței ierarhic superioare prin intermediul contestației prevăzută de art. 347. Astfel, inculpatul are posibilitatea de a critica fie nereţinerea vreunei neregularităţi invocate ale rechizitoriului fie modalitatea în care judecătorul a constatat că rechizitoriul are aptitudinea de a stabili obiectul și limitele judecății. În acest cadru procesual, este mult mai dificil ca instanța de judecată să ajungă la concluzia că rechizitoriul nu a putut stabili în mod corect obiectul și limitele judecății, având în vedere că respectiva împrejurare a făcut obiectul unui dublu control, inclusiv în fața unei instanțe ierarhic superioare, când inculpatul a avut posibilitatea de a aduce critici concrete asupra eventualelor neclarități și lacune ale actului de sesizare în ceea ce privește descrierea faptelor pentru care s-a dispus trimiterea în judecată. Teoretic, o astfel de situaţie ar putea rezulta însă din diferenţele de evaluare realizate ca urmare a parcurgerii dublului grad de jurisdicţie în procedura de cameră preliminară. Astfel, dacă hotărârea judecătorului de cameră preliminară de la instanţa sesizată cu rechizitoriu, prin care s-a dispus restituirea cauzei la parchet ca urmare a existenţei unor neregularităţi neremediate ale actului de sesizare care împiedica stabilirea obiectului şi limitelor judecăţii, este reformată ca urmare a admiterii contestaţiei formulate de către Ministerul Public, judecata va începe şi va trebui realizată de judecătorul iniţial în pofida propriei sale evaluări contrare. Mai mult, dacă motivarea hotărârii de admitere a contestaţiei va întârzia (cum se întâmplă deseori) judecata se va desfăşura în contextul unor incertitudini pentru toţi participanţii la judecată, cu excepţia evident a acuzatorului, existând riscul, în absenţa unui remediu procedural care să supende sau să întârzie judecata, ca dezbaterile pe fond să înceapă înainte ca argumentele pentru care completul care a admis contestaţia şi a decis că nu sunt probleme în ceea ce priveşte claritatea acuzaţiei să fie cunoscute de judecătorul fondului.

Pe de altă parte, prin modificările aduse legislației procesual-penale române, în temeiul deciziilor Curții Constituționale nr. 302/2017, 802/2017 și 88/2019 s-au creat premisele invocării unor nulități absolute ale actelor de urmărire penală ce pot atrage inclusiv neregularități ale actului de sesizare.

d. O primă problemă care se poate ivi în faza judecății este reprezentată de schimbarea încadrării juridice dată faptei. Potrivit art. 342-346 Cod procedură penală, verificarea competenței instanței sesizate se realizează în raport cu încadrarea juridică stabilită de procuror prin rechizitoriu. Judecătorul de cameră preliminară nu poate dispune 
schimbarea încadrării juridice în această procedură, chiar dacă ar constata că aceasta nu corespunde descrierii date faptelor prin actul de sesizare. ${ }^{5}$

Ulterior începerii judecății, prima instanță poate dispune schimbarea încadrării juridice dată faptei prin rechizitoriu într-o infracțiune ce ar putea atrage competența materială sau personală a unei instanțe superioare în grad. În atare situație, în faza judecății se pot crea premisele constatării unei neregularități a rechizitoriului, acesta fiind întocmit de către procurorul necompetent corespunzător încadrării juridice greșite. De asemenea, în raport de noua încadrare juridică și hotărârea de începere a judecății pronunțată de judecătorul de cameră preliminară reprezintă un act al unui organ judiciar necompetent material sau personal.

Potrivit deciziilor nr. 802/2017 și 88/2019, Curtea Constituțională a stabilit cu valoare de principiu că nulitatea absolută a actelor de urmărire penală poate fi invocată în tot cursul procesului penal, inclusiv în faza judecății. În acest cadru, unele instanțe au apreciat că actele judiciare ale organelor necompetente atât în faza de urmărire penală, cât și în procedura camerei preliminare nu pot fi menținute, în caz contrar, fiind lipsite de eficiență dezlegările date de Curtea Constituțională în materia nulității absolute. Pentru acest motiv, soluțiile dispuse au fost de trimitere a cauzei la judecătorul de cameră preliminară de la instanța competentă, acesta urmând a invoca în procedura camerei preliminare nulitatea absolută a actelor de urmărire penală, inclusiv a rechizitoriului pentru a dispune în final restituirea cauzei la procuror pentru refacerea urmăririi penale.

Se poate observa că pentru a pune în acord deciziile Curții Constituționale cu legislația în vigoare, instanțele au reactivat mecanismul prevăzut în fostul art. 332 din Codul de procedură penală de la 1968, dispunându-se restituirea cauzei la parchet din faza de judecată, pe cale indirectă, cu mijlocirea judecătorului de cameră preliminară. Chiar dacă ipoteza analizată nu privește în mod direct drepturile prevăzute de art. 6 alin. (3) și (4) din Directiva 2012/13, această situație poate da naștere necesității restituirii cauzei la parchet din faza de judecată pentru constatarea unei neregularități extrinseci sau intrinseci ale actului de sesizare.

Sub aspect extrinsec, nulitatea actului de sesizare izvorăște din necompetența materială sau personală a procurorului care I-a întocmit, precum și din nulitatea absolută a celorlalte acte de urmărire penală prin care a fost configurată acuzația și care au stat la baza sesizării (ordonanța de punere în mișcare a acțiunii penale, referatul de terminare a urmăririi penale).

Sub aspect intrinsec, stabilirea unei încadrări juridice greșite a faptei pentru care se dispune trimiterea în judecată reprezintă o carență internă a sesizării, ce ține de temeinicia acesteia. Inculpatul nu a avut posibilitatea în faza urmăririi penale să-și exercite dreptul la apărare cu privire la elementele constitutive ale infracțiunii care va constitui obiectul judecății, fiind limitat a formula apărări cu privire la infracțiunea pentru care care va fi judecat exclusiv în fața instanței. De altfel, și sub aspectul schimbării încadrării juridice dată faptei, legiuitorul ar trebui să completeze reglementarea actuală în sensul că aceasta ar trebui dispusă fără a extinde elementele esențiale de tipicitate ale infracțiunii.

În aceste condiții, schimbarea încadrării juridice care ar presupune recalificarea elementelor esențiale ale infracțiunii (de exemplu, din favorizarea făptuitorului în

\footnotetext{
${ }^{5}$ C.A. Cluj, Secția penală, Încheierea nr. 217 din 22 aprilie 2015, I. Neagu, M. Damaschin, A.V. Iugan - Codul de procedură penală adnotat, Editura Universul Juridic, București 2018, pag. 575
} 
complicitate la infracțiunea de omor), nu ar trebui permisă în cursul judecății, întrucât ar echivala cu o transformare esențială a acuzației, inculpatul urmând a fi judecat în fapt pentru o faptă (infracţiune) absolut distinctă de cea pentru care s-a efectuat urmărirea penală și faţă de care și-a realizat apărarea. Sub acest aspect, situația este radical diferită față de cea a unui inculpat pentru a cărui faptă se dispune schimbarea încadrării juridice dintr-o infracțiune în varianta tip într-o infracțiune în variantă calificată ori dacă s-ar modifica elementele circumstanțiale, agravante ori atenuante, împrejurare în care fapta este identică în mod esențial cu cea pentru care s-a dispus trimiterea în judecată, fiind modificate anumite aspecte de fapt de natură a circumstanția activitatea infracțională.

În prima ipoteză prezentată, apreciem că schimbarea încadrării juridice ar trebui să presupună întotdeauna restituirea cauzei în vederea completării urmăririi penale și a refacerii actului de sesizare. Unde ar trebui însă să se dispună restituirea cauzei ? La parchet sau la procuror ? Nuanţa este importantă pentru că presupune diferenţe în ceea ce priveşte mecanismul procedural prin care se realizează reluarea urmăririi penale în actualul sistem procesual penal ${ }^{6}$. În raport cu reglementarea actuală (art. 334 C.proc.pen.), în cazul constatării unor neregularități ale actului de sesizare care împiedică stabilirea obiectului sau a limitelor judecății, cauza este restituită la parchet, conducătorului parchetului revenindu-i competenţa exclusivă de a analiza și stabili în ce măsură este necesară reluarea urmăririi penale în vederea înlăturării carenţelor actului de sesizare. Practic, dispoziţia de reluare a urmării penale se emite doar în măsura în care se constată că remedierea neregularităţii implică în mod necesar efectuarea unor acte de urmărire penală, în caz contrar, intervenţia procurorului competent asupra actului de sesizare fiind permisă şi fără reluarea urmăririi penale. Astfel, reglementarea actuală instituie un fel de filtru suplimentar destinat a tempera consecinţele excesive ale dispoziţiei de restituire a cauzei şi care instituie un monopol în favoarea Ministerului Public.

Această inovaţie procedurală, deşi circumscrisă evident nevoii de asigurare a unei durate rezonabile procedurii judiciare, este criticabilă sub mai multe aspecte.

În primul rând, prin consacrarea posibilităţii ca remedierea actului de sesizare să se realizeze fără a se dispune reluarea urmăririi penale este recunoscută, în mod implicit, abilitatea conducătorului parchetului de a extinde, unilateral, posibilitatea procurorului de caz de a se manifesta judiciar deşi funcţia sa naturală, care îi oferă şi competenţa funcţională de a se exprima prin acte adecvate, a fost pierdută prin dezînvestire. Or, această manifestare are loc într-un cadru procesual nenumit, creat artificial pe cale judiciară fără remedii şi garanţii care să permită un control, chiar intern, de legalitate şi temeinicie.

Apoi, această competenţă exclusivă instituită în sarcina unui reprezentant al Ministerului Public intră în conflict cu limitele în care este reglementat raportul funcțional dintre judecătorul de cameră preliminară şi procuror. Subliniind ca acest tip de intervenţie sui generis nu are loc în etapa incidentală sau remedială din procedura de cameră preliminară, prevăzută de art. 345 alin.(3) C.proc.pen., ci după finalizarea procedurii şi dezînvestirea judecătorului de cameră preliminară, este posibil ca intervenţia procurorului asupra actului de sesizare fără reluarea urmăririi penale să ignore dezlegările definitive ale judecătorului de cameră preliminară.

\footnotetext{
${ }^{6}$ A se vedea în acest sens A. Zarafiu, Procedură penală. Partea generală. Partea specială, Ediția 2, Editura C.H. Beck, București 2015, p. 388
} 
Premisa esenţială pentru restituirea în temeiul art. 346 alin.(3) lit. a C.proc.pen. este constatarea definitivă, pe cale judecătorească, a existenţei unei neregularităţi care împiedică stabilirea obiectului sau a limitelor judecăţii. Această implică, prin natura sa, o carenţă nu formală ci de conţinut a acuzaţiei care se reverberează în imposibilitatea stabilirii unui cadru procesual previzibil şi accesibil pentru desfăşurarea judecăţii. În mod natural, pentru a avea aptitudinea funcţională de a înlătura o astfel de carenţă, orice intervenţie asupra actului de sesizare trebuie să fie corolarul unei noi manifestări procesuale - de extindere, de abreviere, de completare, de nuanţare, de explicitare etc.. - care vizează elemente factuale sau juridice ale acuzaţiei. Or, această manifestare presupune în mod obligatoriu reactivarea funcţiei de urmărire pierdute prin dezînvestire. A accepta astfel intervenţia asupra actului de sesizare fără reluarea urmăririi penale înseamnă implict să permitem conducătorului parchetului să limiteze sau chiar să ignore constatările definitive ale judecătorului de cameră preliminară,

$\mathrm{Nu}$ în ultimul rând, în pofida naturii sale juridice unice (în sensul că este un act caracterizat atât din perspectiva formei, cât şi a conţinutului), în contextul global al acuzaţiei penale ce urmează să fie analizată de instanţa de judecată, rechizitoriul este el însuşi corolarul unor acte procesuale prin care această acuzaţie a fost configurată succesiv ordonanţa de efectuare a urmăririi penale in personam, ordonanţa de punere în mişcare a acţiunii penale. Existenţa unei carenţe în actul de sesizare, care împiedică stabilirea obiectului şi limitelor judecăţii, implică aproape în mod natural existenţa aceluiaşi tip de carenţe în actele procesuale care l-au precedat. Astfel, intervenţia punctuală asupra rechizitoriului nu va fi prin ea însăşi suficientă pentru a înlătura ceea ce va deveni o problemă de legalitate a sesizarii - absenţa unei suprapuneri complete între actele prin care, succesiv, a fost configurată acuzaţia.

În schimb, restituirea cauzei la procuror, provocată de exemplu de dispoziţia, tot definitivă a judecătorului de cameră preliminară care desfiinţează, în procedura de soluţionare a plângerii formulate în temeiul art. 340 C.proc.pen., o soluţie de clasare sau, în procedura de confirmare prevăzută de art. 318 C.proc.pen., o soluţie de renunţare la urmărirea penală, determină o reluare obligatorie şi de nerefuzat a urmăririi penale. Această dispoziţie nu poate fi ignorată sau diluată prin intervenţia conducătorului parchetului care pierde inclusiv competenţa de a stabili limitele (în sensul de acte ce trebuie efectuate) în care se va produce reluarea. Aceste limite sunt stabilite prin dispoziţia judecătorului de cameră preliminară, fiind obligatorii pentru organul de urmărire penală care va proceda la efectuarea urmăririi penale după reluare, potrivit dispoziţiilor art. 335 alin.(5) C.proc.pen.

Posibilitatea restituirii cauzei direct la procuror era prevăzută în art. 300 alin. (2) din Codul de procedură penală de la 1968, potrivit căruia, în cazul în care se constata că sesizarea nu era făcută potrivit legii, iar neregularitatea nu putea fi înlăturată de îndată şi nici prin acordarea unui termen în acest scop, dosarul se restituia organului care a întocmit actul de sesizare, în vederea refacerii acestuia ${ }^{7}$.

Aşadar, în considerarea acestor explicaţii funcţionale, în cazul schimbării încadrării juridice ce presupune o modificare esențială a calificării în drept a acuzației, aplicarea

\footnotetext{
7 în doctrină a fost exprimată opinia potrivit căreia, într-o astfel de ipoteză, procesul rămânea în aceeași fază procesuală, neoperând o dezînvestire a instanței, cauza fiind restituită procurorului exclusiv pentru întocmirea unui nou act de sesizare - A. Crișu, Drept procesual penal, Partea specială, Ediția a 2-a, revizuită și actualizată, Ed. Hamangiu, București, 2020, p. 506.
} 
directă a jurisprudenței CJUE prevăzută în cauza ZX, ar trebui să implice o dispoziţie de restituire a cauzei la procuror. Dispoziţia instanţei de judecată va determina o reluare obligatorie a urmăririi penale pentru a da posibilitatea inculpatului să-și exercite corespunzător dreptul la apărare în raport cu noile informații ce caracterizează în drept fapta cu privire la care s-a formulat acuzația în materie penală.

e. O a doua problemă ce poate izvorî din aplicarea Deciziilor nr. 802/2017 și 88/2019 ale Curții Constituționale privește efectul derivat al nulităților absolute constatate în faza judecății, conform art. 280 alin. (2) din Codul de procedură penală.

În paragraful 29 al Deciziei nr. 802/2017, Curtea Constituțională reține că: „o verificare a loialității/legalității administrării probelor, din această perspectivă [art. 101 și art. 102 alin. (1) din Codul de procedură penală], este admisă și în cursul judecății, aplicânduse, în acest mod, regula generală potrivit căreia nulitatea absolută poate fi invocată pe tot parcursul procesului penal. Așadar, interdicția categorică a legii în obținerea probelor prin practici/procedee neloiale/nelegale justifică competența judecătorului de fond de a examina și în cursul judecății aceste aspecte. Altfel spus, probele menținute ca legale de judecătorul de cameră preliminară pot face obiectul unor noi verificări de legalitate în cursul judecății din perspectiva constatării inadmisibilității procedurii prin care au fost obținute și a aplicării nulității absolute asupra actelor procesuale și procedurale prin care probele au fost administrate, în condițiile în care, în această ipoteză, se prezumă iuris et de iure că se aduce atingere legalității procesului penal, vătămarea neputând fi acoperită".

Prin Decizia nr. 88/2019, Curtea Constituțională a reiterat regulile specifice regimului juridic al nulității absolute, statuând că dispozițiile art. 281 alin. (4) lit. a) din Codul de procedură penală nu pot limita dreptul părților de a invoca în tot cursul judecății nulitatea absolută a actelor de urmărire penală ce decurge din încălcarea normelor privind asistența juridică obligatorie ${ }^{8}$. În această situație, încălcarea normelor privind asistența juridică obligatorie a părților poate vicia inclusiv procedeele probatorii efectuate în cursul urmăririi

\footnotetext{
8 "45. Curtea observă că raţiunea unei astfel de dispoziţii referitoare la stabilirea unui termen până la care poate fi invocată nulitatea absolută poate fi generată de rolul fazei procesuale a camerei preliminare, care trebuie să examineze tocmai neregularităţile de procedură ivite înaintea fazei de judecată, pentru ca aceasta din urmă să dobândească celeritatea impusă de cerinţa soluţionării cauzei într-un termen rezonabil. Astfel, Curtea constată că reglementarea unei noi structuri a procesului penal coroborată cu necesitatea soluţionării cauzei (faza de judecată) într-un termen rezonabil ar fi un motiv ce stă la baza opţiunii legiuitorului de a norma în anumite cazuri un termen până la care nulitatea absolută poate fi ridicată.

46. În acest context, Curtea constată că soluţionarea cauzei într-un termen rezonabil se circumscrie unui scop legitim, iar reglementarea unei noi structuri a procesului penal poate determina şi justifica anumite opţiuni legislative. Cu toate acestea, Curtea reţine că în jurisprudenţa sa (...) a constatat că rezultatul procedurii în camera preliminară referitor la stabilirea legalităţii administrării probelor şi a efectuării actelor procesuale de către organele de urmărire penală are o influenţă directă asupra desfăşurării judecăţii pe fond, putând să fie decisiv pentru stabilirea vinovăţiei/nevinovăţiei inculpatului. Or, având în vedere importanţa acestei etape, precum şi faptul că, în cazurile pentru care legea reglementează asistenţa obligatorie, dreptul la apărare nu poate fi exercitat în mod efectiv decât prin prezenţa apărătorului, Curtea constată că reglementarea unei noi faze a procesului penal nu reprezintă un motiv întemeiat, care să justifice legiferarea unui termen (încheierea procedurii în camera preliminară) până la care încălcarea dispoziţiilor legale referitoare la asistarea obligatorie a inculpatului intervenită în procedura camerei preliminare să poată fi invocată.

47. În ceea ce priveşte soluţionarea cauzei într-un termen rezonabil, Curtea constată că acesta este un deziderat dorit a fi atins în ceea ce priveşte toate cauzele/procedurile judiciare. Cu toate acestea, soluţionarea cauzei într-un termen rezonabil nu se poate converti în justificarea ce stă la baza unei reglementări ce afectează însuşi dreptul la apărare şi dreptul la un proces echitabil."
} 
penale, determinând excluderea unor mijloace de probă care au stat la baza emiterii dispoziției de trimitere în judecată. Însă, această sancțiune derivată din sancțiunea procedurală a nulității, nu trebuie să aibă natura doar a unei excluderi juridice, ci aceasta trebuie să se realizeze în mod efectiv, prin înlăturarea fizică a mijloacelor de probă obținute cu încălcarea dispozițiilor legale.

În acest sens, Curtea Constituțională a clarificat această problemă, apreciind în considerentele Deciziei nr. 22/2018 necesitatea înlăturării fizice a acestora atât din materialul probator, cât și din cuprinsul rechizitoriului ori a altor acte procesuale care au configurat acuzația. În motivarea deciziei anterior menționate, admițând excepția de neconstituționalitate cu privire la dispozițiile art. 102 alin. (3) din Codul de procedură penală, Curtea a statuat că „excluderea juridică a probelor obținute în mod nelegal în procesul penal, în lipsa înlăturării lor fizice din dosarele penale constituite la nivelul instanțelor, este insuficientă pentru o garantare efectivă a prezumției de nevinovăție a inculpatului și a dreptului la un proces echitabil al acestuia." [paragraful 24]

Instanța de control constituțional învederează faptul că „eliminarea fizică $a$ mijloacelor de probă din dosarele penale, cu ocazia excluderii probelor aferente, prin declararea lor ca fiind nule, conform prevederilor art. 102 alin. (3) din Codul de procedură penală, excludere ce presupune atribuirea unei duble dimensiuni sensului noțiunii de "excluderea probei» - respectiv dimensiunea juridică și cea a eliminării fizice, - este de natură a garanta, de o manieră efectivă, drepturile fundamentale mai sus invocate, asigurând, totodată, textului criticat un nivel sporit de claritate, precizie și previzibilitate.

Prin urmare, Curtea reține că doar în aceste condiții instituția excluderii probelor își poate atinge finalitatea, aceea de a proteja atât judecătorul, cât și părțile de formarea unor raționamente juridice și de pronunțarea unor soluții influențate, direct sau indirect, de potențiale informații sau concluzii survenite ca urmare a examinării sau reexaminării empirice, de către judecător, a probelor declarate nule". [paragraful 27]

Date fiind aceste dezlegări pronunțate de Curtea Constituțională, rezultă că nu este suficientă doar excluderea fizică a probelor nelegal administrate din cuprinsul materialului probator, ci devine necesară inclusiv înlăturarea fizică a oricăror pasaje sau referiri la acestea, atât din cuprinsul actului de sesizare, cât și din alte acte procesuale care au condus la configurarea acuzației.

În caz contrar, a menține în rechizitoriu referirile la mijloacele de probă excluse în raport de care procurorul descrie fapta pentru care a dispus trimiterea în judecată, înseamnă a ignora Decizia nr. 22/2018 a instanței de control constituțional ale cărei considerente sunt general obligatorii erga omnes ${ }^{9}$.

\footnotetext{
${ }^{9}$ Eliminarea respectivelor mențiuni din conținutul actelor procesuale se impune în egală măsură și pentru aceleași rațiuni avute în vedere în DCC nr. 22/2018, căci, în caz contrar, se anulează chiar efectul excluderii fizice a mijloacelor de probă, în condițiile în care despre existența și chiar conținutul acestora, se face mențiune expresă și detaliată în rechizitoriu și ordonanța de regularizare a actului de sesizare. Altfel spus, contrar rațiunilor ce determină îndepărtarea mijloacelor de probă a căror nulitate a fost constatată, s-ar ajunge ca faptele și împrejurările relevate prin probele excluse să fie în continuare cunoscute și evidențiate prin acte esențiale pentru soluționarea cauzei.

Or, în speță, se constată că, pe lângă simpla indicare a acestor mijloace de probă și a modului în care s-a dispus autorizarea măsurilor de supraveghere tehnică, în cuprinsul rechizitoriului se procedează la analiza detaliată a acestora și la o amplă redare a conținutului probelor obținute prin punerea în executare a măsurilor de supraveghere tehnică. (...) Luând în considerare rațiunile ce au stat la baza deciziei nr. 22/2018 a Curții Constituționale, păstrarea acestor mențiuni în cuprinsul celor două acte procesuale ar anula consecințele
} 
Așa cum am menționat anterior, chiar dacă, de principiu, sancțiunea nulității și, implicit, a excluderii în faza de judecată a mijloacelor de probă obținute cu încălcarea dispozițiilor legale reprezintă în fapt rezultatul evaluării instanței, și nu o chestiune ce ține de neregularitatea actului de sesizare. În realitate, menținerea în cuprinsul rechizitoriului a oricăror pasaje preluate sau referiri la aceste probe excluse în considerarea dispozițiilor art. 102 alin. (2) şi (3) din Codul de procedură penală, precum și a Deciziei nr. 22/2018 a Curții Constituționale, determină în concret o neregularitate implicită a actului de sesizare.

Prin urmare, doar excluderea fizică a mijloacelor de probă din materialul de urmărire penală nu este suficientă pentru a satisface exigențele impuse de instanța de contencios constituțional, de vreme ce în actele procesuale prin care procurorul și-a configurat acuzațiile de natură penală imputate inculpatului sunt prezentate în continuare împrejurări de fapt rezultate din mijloacele de probă nelegal sau neloial administrate. Într-o asemenea ipoteză, efectul cognitiv cu privire la care Curtea Constituțională a făcut referire în decizia nr. 22/2018 nu a fost înlăturat, nefiind asigurată garantarea efectivă a prezumției de nevinovăție a inculpatului și a dreptului său la un proces echitabil decât într-o modalitate aparentă, iluzorie, fapt ce, în opinia noastră, se convertește într-o carență a sesizării în ansamblul său.

Având în vedere dispozițiile art. 6 alin. (3) și (4) din Directiva 2012/13, instanței îi revine obligația ca, în cazul excluderii unor probe în faza judecății să interpreteze dreptul național astfel încât să poată asigura, înainte de deschiderea dezbaterilor pe fondul cauzei, o nouă informare a inculpatului cu privire la temeiul de fapt și de drept al acuzației. Această informare asupra elementelor esențiale ale acuzației trebuie să presupună o nouă descriere a situației de fapt, în raport cu mijloacele de probă care o susțin, pentru ca inculpatul să poată cunoaște probele în baza cărora Parchetul urmărește a dovedi fapta pentru care I-a trimis în judecată și a apreciat că sunt întrunite elementele constitutive ale unei infracțiuni.

Împrejurarea că dezlegările obligatorii pronunțate de Curtea Constituțională prin Decizia nr. 22/2018 nu au fost nici în prezent transpuse la nivel legislativ, a determinat apariția unei lacune legislative în privința mecanismului procesual prin care această neregularitate poate fi remediată în procedura de cameră preliminară.

Mecanismul existent prevăzut de art. 345 alin. (3) din Codul de procedură penală este ineficient, întrucât oferă o soluție doar în situația în care excluderea probelor nelegal administrate în cursul urmăririi penale $s$-a dispus în procedura camerei preliminare și nu stabilește un raport de cauzalitate între efectul excluderii probelor în raport cu care a fost descrisă fapta ce constituie obiectul judecății și neregularitatea actului de sesizare. În concret, excluderea unor probe în procedura de cameră preliminară naște un drept al procurorului de a analiza suficiența probatoriului în funcție de care va continua exercitarea acțiunii penale în fața instanței, acesta având opțiunea de a solicita restituirea cauzei la parchet pentru completarea urmăririi penale și în final reanalizarea temeiniciei dispoziției de trimitere în judecată.

Dispozițiile art. 345 alin. (3) din Codul de procedură penală nu dau dreptul inculpatului de a repune în discuție neregularitatea actului de sesizare pentru a solicita excluderea din rechizitoriu a pasajelor care fac trimitere la mijloacele de probă excluse și a

excluderii probelor nelegale și ar genera efectul invers celui urmărit de Curtea Constituțională prin decizia menționată, conducând, implicit, la afectarea prezumției de nevinovăție și a dreptului la un proces echitabil al inculpatului. Înalta Curte de Casație și Justiție - Completul de 2 judecători de cameră preliminară, încheierea nr. 31/C din 27.09.2018, nepublicată. 
solicita restituirea cauzei la parchet, întrucât descrierea faptei nu permite stabilirea obiectului și a limitelor judecății. Este adevărat că unele instanțe au făcut o aplicare directă a jurisprudenței Curții Constituționale, constatând neregularitatea actului de sesizare și obligând parchetul a elimina din rechizitoriu pasajele ce fac trimitere la mijloacele de probă excluse, însă, sub aspectul standardului de previzibilitate al normei de drept procesual penal, Curtea Europeană a Drepturilor Omului a arătat că lacunele legislative pot fi atenuate numai printr-o jurisprudență constată și unitară a instanțelor judecătorești, aptă a crea în mod previzibil drepturi procesuale pentru inculpat. Astfel, o jurisprudență izolată a instanțelor este de natură a menține echitatea procedurii într-o speță individual determinată, însă nu îndeplinește criteriile necesare suplinirii unei lacune legislative a normelor de drept procesual penal.

Pe de altă parte, în cursul judecății, deși instanțele sunt obligate a invoca din oficiu în orice stadiu al procedurii nulitățile absolute ale actelor prin care au fost administrate probe în faza urmăririi penale, urmând a exclude juridic și material mijloacele de probă obținute cu încălcarea dispozițiilor prevăzute în art. 281, 101 și 102 alin. (1) din Codul de procedură penală, acestea nu au un remediu juridic pentru a rediscuta regularitatea unui rechizitoriu care a inclus la descrierea situației de fapt mijloacele de probă excluse și nici pentru a dispune restituirea cauzei ori a actului de sesizare la parchet, pentru remedierea acestuia ori refacerea urmăririi penale.

În acest cadru normativ, absența unor dispoziţii exprese care să stabilească la nivel procedural o modalitate de remediere a neregularităţilor actului de sesizare creează premisa adoptării unor soluții exclusiv pe cale judiciară, fără a avea un fundament normativ. În doctrină, au fost conturate două remedii, primul presupunând o intervenţie directă a procurorului asupra actelor procesuale şi procedurale prin care să fie adusă la îndeplinire dispoziţia judecătorului de cameră preliminară ori a instanței de excludere fizică a probelor nelegale sau neloiale, fără a opera o dezînvestire a instanței. Cel de-al doilea remediu presupune o restituire a cauzei fie la parchet, fie chiar la procuror, după distincţiile antereferite.

Potrivit unei prime opinii exprimate în doctrină ${ }^{10}$, concluziile evocate hotărârea pronunțată în cauza ZX sunt supuse unei modalități de interpretare alternativă, în sensul în care restituirea cauzei la parchet reprezintă varianta subsidiară, în măsura în care procurorul nu poate compensa, direct în fața instanței, deficiențele acuzației. În acest sens, a fost recomandată parcurgerea mecanismului prevăzut de art. 345 și 346 Cod procedură penală în două etape, respectiv constatarea de către instanță a neregularităților actului de sesizare și solicitarea ca procurorul să remedieze neregularitatea. Dacă neregularitatea nu este remediată, iar aceasta împiedică stabilirea obiectului sau a limitelor judecății, instanța urmează să dispună restituirea cauzei la parchet, urmând a se proceda potrivit art. 334 alin. (2) Cod procedură penală.

În opinia noastră, fie că vom considera cele două remedii ca fiind instituite în mod alternativ sau într-o ordine de preferință (varianta primară - remedierea neregularităților direct în faza judecății, urmată de cea subsidiară - restituirea cauzei la parchet), este cert că hotărârea CJUE evocă două mecanisme compensatorii care pot opera, in extremis, pentru a garanta exigențele ce țin de claritatea acuzației chiar în momente avansate ale procedurii,

\footnotetext{
${ }^{10} R$. Slăvoiu, în ce condiții este într-adevăr aplicabilă, în procesul penal român, decizia CJUE din cauza c-282/20 ZX? - www.juridice.ro
} 
înainte de rezolvarea cauzei pe fond.

Ambele remedii se raportează la titularul originar al acuzației, respectiv Ministerul Public, singurul organ competent funcțional să acționeze în această materie, însă trebuie remarcat că acestea se manifestă din punct de vedere procedural în forme diferite. În aceste condiții, o primă formă presupune reactivarea competenței funcționale pierdute de procuror în momentul desesizării prin emiterea rechizitoriului și începerea judecății, care iar permite să intervină asupra acuzației direct în fața instanței, fie prin reconfigurarea aspectelor formale (externe) ori a celor de conținut (interne). A doua formă se subsumează aceleiași finalități, însă reactivarea competenței funcționale va presupune și reactivarea cadrului procesual adecvat în care aceasta se poate manifesta, respectiv reluarea urmăririi penale în urma restituirii cauzei.

Cu titlu preliminar, trebuie subliniat că formularea acuzației, îndeosebi când se materializează în forma procedurală ce declanșează și transferul de competențe funcționale spre organele jurisdicționale - trimiterea în judecată - este atributul exclusiv al Ministerului Public, fiind actul procesual în care se concentrează funcția judiciară de urmărire penală. Pentru acest motive, ambele remedii implică, în mod natural, intervenția titularului acuzației.

Totodată, ambele remedii evocate de hotărârea CJUE nu cunosc un corolar judiciar concret în sistemul nostru de drept, întrucât acestea vin în conflict cu modalitatea în care a fost conceput mecanismului de manifestare succesivă a funcțiilor judiciare. Bazându-se pe același mecanism de operare, aplicarea oricăruia ar presupune o manifestare procedurală contestată de realitățile normative actuale.

Data fiind preeminența dreptului european, apreciem că principala problema pe care hotărârea o angajează este care dintre cele doua remedii ar trebui preferat. În orice caz, aplicarea simultană a acestora este exclusă la nivel funcțional.

Analizând primul remediu, apreciem că, posibilitatea intervenției directe a procurorului în faza de judecată nu are, prin ea însăşi, aptitudinea funcţională de a satisface exigenţele impuse de art. 3 din Codul de procedură penală, și nici ale instanței de contencios constituțional pentru punerea în aplicare a Deciziei nr. 22/2018.

Pentru a fi eficientă, intervenţia directă presupune existenţa a două condiţii cumulative - pe de-o parte, activarea contextului procesual adecvat care să permită exercitarea, de către un organ judiciar care deja s-a dezînvestit odată cu trimiterea în judecată, a unor atribuţii judiciare şi, pe de altă parte, aptitudinea obiectivă a acestui remediu de a realiza finalitatea pe care o presupune îndepărtarea fizică sau materială a probelor excluse.

Din perspectiva abilitării procurorului de a se manifesta judiciar în procedura de cameră preliminară ori în cursul judecății, trebuie observat că singura funcţie activă în aceaste proceduri este doar cea a judecătorului de cameră preliminară ori a instanței de judecată. Legea nu permite un transfer temporar de atribuţii judiciare, câtă vreme judecătorul de cameră preliminară sau instanța nu s-au dezînvestit astfel că, în mod funcţional, reprezentantul Ministerului Public nu se poate manifesta decât după ce funcţia sa naturală, anterior pierdută, se va reactiva.

Or, singura modalitate procedurală de reactivare a funç̧iei care i-ar permite procurorului să emită sau să intervină asupra actelor care au configurat acuzaţia penală ce face obiectul trimiterii în judecată este reluarea urmăririi penale determinată de restituirea cauzei la procuror. 
În acelaşi timp, nici din perspectiva finalităţii sale materiale, intervenţia directă nu are aptitudinea de a înlătura în mod real informaţiile devenite ineficace ca urmare a excluderii, de vreme ce, rechizitoriul şi celelalte acte procesuale de punere sub acuzare rămân în forma lor iniţială.

Fie că imbracă forma unui proces-verbal de îndreptare eroare materială sau a unui referat cu menţiunea îndepărtării, această intervenţie rămâne lipsită de efectivitate întrucât operează exclusiv la nivel judiciar.

Or, premisa esenţială a Deciziei Curţii Constituţionale nr. 22/2018 este circumscrisă nevoii de îndepărtare propriu-zisă, fizică, a oricărui suport în care s-au obiectivat probele nelegale sau neloiale. Doar prin înlăturarea materială dispare, în mod complet, riscul valorificării insidioase, pe plan cognitiv, a unor probe ce nu mai pot fi utilizate judiciar. Din această perspectivă, preluarea în cuprinsul actelor procesuale a unor pasaje din probele excluse nu poate fi remediată decât prin emiterea unor acte noi, care să le înlocuiască pe cele compromise. Or, astfel de operaţiuni pot fi realizate doar de către Ministerul Public, acestea fiind atribute exclusive ale procurorului, iar la acest moment procesual, acesta nu mai are competenţa funcţională pentru efectuarea unor asemenea demersuri.

Pe cale de consecinţă, în opinia noastră, remedierea neregularității actului de sesizare prin restituirea cauzei şi reactivarea funcţiei judiciare de urmărire penală este preferabilă intervenției directe a procurorului în faza de judecată, reprezentantul Ministerului Public având posibilitatea ca, în ipoteza în care doreşte să îşi menţină dispoziţia de trimitere în judecată, să poată reface actele procesuale şi să emită un nou rechizitoriu, din cuprinsul căruia să elimine orice pasaje preluate sau referiri la probele administrate cu încălcarea dispoziţiilor legale.

Odată cu pronunțarea hotărârii CJUE în cauza ZX, o cale judiciară care să permită inculpatului a solicita ca procurorul să remedieze neregularitățile și lacunele actului de sesizare în faza judecății, protejând în același timp dreptul la apărare, devine obligatorie, instanța trebuind să interpreteze normele dreptului național în conformitate cu art. 6 alin. (3) din Directiva 2012/13 și art. 47 CDFUE.

Spre deosebire de dreptul bulgar, în dreptul procesual penal român, nu există o norma expresă care să interzică instanței restituirea cauzei la parchet sau la procuror în faza judecății. Prin întreaga configurație a procesului penal, legiuitorul a creat etapa camerei preliminare, în cadrul căreia judecătorul poate pronunța două soluții specifice, respectiv începerea judecății sau restituirea cauzei la parchet. În etapa judecății în primă instanță și în apel, se poate realiza exclusiv o judecată pe fond a cauzei, urmând ca instanța să se pronunțe asupra angajării sau nu a răspunderii penale a inculpatului în raport cu probele legal administrate.

Astfel, evaluarea regularității actului de sesizare și judecata pe fond sunt activități atribuite unor organe judiciare diferite, respectiv judecătorul de cameră preliminară și instanța de judecată. Chiar dacă, în fapt, aceeași persoană va îndeplini atribuțiile celor două organe judiciare, din punctul de vedere al competenței funcționale instanța de judecată nu poate exercita atribuțiile judecătorului de cameră preliminară și nici în sens invers. Acest specific al procedurii penale române se delimitează de raționamentul CJUE din cauza ZX, întrucât, potrivit dreptului bulgar, același organ judiciar, respectiv instanța de judecată, avea competență funcțională atât în cadrul ședinței preliminare, cât și în cel al al judecății în primă instanță. Pentru acest motiv, în respectiva speță, CJUE a apreciat că instanța poate 
lăsa neaplicată o interdicție legală pentru a efectua un act de procedură care, potrivit legii, intra în domeniul de aplicare al competenței sale funcționale.

\section{CONCLUZII}

Față de aceste aspecte, în aplicarea hotărârii CJUE pronunțate în cauza ZX, trebuie luat în considerare faptul că ambele remedii propuse - intervenţia directă a procurorului asupra actului de sesizare în faza judecăţii şi restituirea cauzei fie la parchet fie la procuror vin în conflict cu felul în care a fost concepută arhitectura procesului penal actual. Dezînvestirea instanţei şi reactivarea unui cadru care să permită parcurgerea tuturor etapelor procedurale cu garantarea drepturilor acuzatului este însă de preferat.

Această analiză a opțiunii pentru preferința unuia dintre remedii ar trebui realizată și prin raportare la alte exigențe ce țin de echitatea procedurii. Chiar dacă, la o primă vedere, o intervenție directă a procurorului asupra acuzației în cursul judecății s-ar circumscrie nevoii de asigurare a unui termen rezonabil al procedurii, prețul plătit, din perspectiva drepturilor acuzatului, ar fi mult prea mare. De altfel, și CJUE prin hotărârea pronunțată la 12 februarie 202 în cauza C-704/18, precum și prin ordonanța din 14 ianuarie 2021 în cauza C-769/19 s-a exprimat în același sens, imperativul soluționării cauzei într-un termen rezonabil nefiind de natură a conduce la nesocotirea normelor privind competența funcțională a organelor judiciare ori la restrângerea dreptului la apărare.

Mai mult, soluția intervenției directe a procurorului pentru remedierea neregularităților ar putea intra în conflict și cu jurisprudența CEDO și CJUE în materia dreptului la apărare și a asigurării dublului grad de jurisdicție. Astfel, dacă solicitările de excludere a unor probe administrate în cursul urmăririi penale, în raport cu care acuzația a fost descrisă în mod determinant, vor fi formulate şi admise în cursul judecăţii în apel (dispoziţie care să includă şi înlăturarea preluărilor şi referirilor la acestea din conţinutul rechizitoriului şi a celorlalte acte procesuale), remedierea neregularității rechizitoriului de procuror direct în apel ar îngrădi accesul inculpatului la dublul grad de jurisdicție. De exemplu, dacă instanța de apel ar reține că descrierea faptei pentru care s-a dispus trimiterea în judecată este conturată de conținutul convorbirilor telefonice interceptate nelegal, urmată de redarea acestora, excluderea respectivelor interceptări și continuarea judecății în urma remedierii neregularităților rechizitoriului în calea de atac a apelului, ar echivala în fapt cu accesul inculpatului la un unic grad de jurisdicție pentru fapta cu privire la care a fost trimis în judecată, respectiv judecata în apel.

Mai mult, soluția restituirii este de preferat, întrucât, timid, a mai fost acceptată judiciar, chiar dacă a fost pronunțată după începerea judecății - în cazul constatării nulității absolute a actelor de urmărire penală efectuate cu încălcarea normelor de competență materială simplă, specializată ori chiar de competenţă funcţională. În practică, atât instanțele, cât și judecătorii de cameră preliminară s-au orientat către aplicarea acestei soluții, dispunând direct restituirea cauzei la parchet în cazul constatării unor neregularități ale actului de sesizare ce au decurs din descrierea situației de fapt prin raportare la mijloacele de probă excluse.

Nu în ultimul rând, menținerea unui rechizitoriu neregulamentar întocmit sub aspectul descrierii faptelor, în condițiile în care acesta cuprinde pasaje preluate din mijloacele de probă, care au fost excluse în mod legal de către instanță, conduce la o încălcare flagrantă atât a Deciziei Curții Constituționale nr. 22/2018, cât și a art. 6 alin. (3) 
din Directiva 2012/13, împrejurare care este de neacceptat. În acest cadru, opinăm că ulterior excluderii unor mijloace de probă în faza judecății, instanța ar trebui să pună în discuție regularitatea actului de sesizare în conținutul căruia au fost preluate pasaje din respectivele mijloace de probă, urmând a pronunța direct în baza art. 47 CDFUE și a art. 6 alin. (3) din Directiva 2012/13 o sentinţă de desesizare și de restituire a cauzei.

Pentru argumentele amplu dezvoltate supra, dispoziţia instanţei de judecată ar trebui să fie de restituire a cauzei la procuror şi nu la parchet, întrucât parcurgerea filtrului procedural pe care îl presupune restituirea la parchet şi care implică abilitarea exclusivă a conducătorului parchetului de a evalua în ce măsură se impune reluarea urmăririi penale (potrivit dispoziţiilor art. 334 C.proc.pen.) este, în acest caz, superfluă. Luând în considerare natura incidentelor care provoacă imposibilitatea continuării judecăţii în ipotezele analizate, aplicarea directă a jurisprudenţei CJUE ar trebui să determine o reluare obligatorie a urmăririi penale circumscrise nevoii de înlocuire a actelor compromise prin care s-a configurat succesiv acuzaţia formulată în materie penală.

Chiar dacă acceptăm opinia ${ }^{11}$ potrivit căreia, formal, rechizitoriul nu este un act de urmărire penală (în sensul său originar), este de neacceptat posibilitatea întocmirii de acte specifice funcţiei de urmărire penală, fie autonome, fie completatoare, fără reactivarea cadrului procesual adecvat în care aceasta să fie exercitată. Mai mult, câtă vreme rechizitoriul este corolarul actelor procesuale succesive care îi justifică existenţa şi care, împreună, configurează în mod global acuzaţia ce face obiectul judecăţii (ordonanţa de efectuare a urmăririi penale in personam, ordonanţa de punere în mişcare a acţiunii penale), ar fi de neacceptat intervenţia singulară asupra actului de sesizare fără intervenţia echivalentă asupra actelor anterioare şi emiterea unora noi. Or, această intervenţie implică în mod natural reluarea urmăririi penale fără parcurgerea filtrului aplicat de conducătorul parchetului.

În aceeași măsură, dacă în procedura camerei preliminare au fost excluse mijloace de probă care se regăsesc în conținutul rechizitoriului, și judecătorul de cameră preliminară este obligat în baza efectului direct al acelorași dispoziții de drept european să repună în discuție neregularitatea actului de sesizare și față de analiza anterior expusă privind competența funcțională a procurorului în cadrul acestei proceduri judiciare, să dispună restituirea cauzei pentru întocmirea unui nou act de sesizare.

\footnotetext{
${ }^{11}$ I. Kuglay, în Codul de procedură penală, Comentariu pe articole, M. Udroiu (coordonator), Ed. C.H.Beck, Bucureşti, 2015, p.905.; M. Udroiu, Procedură penală. Partea specială, Ediţia 5, Ed. C.H.Beck, 2015, p.182. Critica principală ce poate fi adusă acestei opinii este că, prin nedezvoltarea argumentelor, induce ideea că după terminarea urmăririi penale, în accepţiunea tehnică stabilită prin dispoziţiile art. 321-323 C.proc.pen., manifestările judiciare ale procurorului nu pot îmbrăca forma actelor de urmărire penală. Din perspectivă funcţională, şi soluţiile dispuse de procuror după terminarea urmăririi penale (inclusiv trimiterea în judecată), şi eventuala ordonanţă de reluare sau de redeschidere a urmăririi penale sunt tot acte de urmărire penală în sensul de forme procedurale prin care se manifestă judiciar organul care exercită funcţia de urmărire penală. Mai mult, prin natura sa, rechizitoriul este actul în care se concentrează esenţa funcţiei de urmărire penală întrucât este unica formă în care poate fi înglobată dispoziţia pozitivă prin care se realizează scopul procedural al fazei de urmărire penală, evocat prin dispoziţiile art. 285 C.proc.pen. - dispoziţia de trimitere în judecată. Poziţia diferită pe care o ocupă rechizitoriul în cadrul actelor supuse evaluării în procedura de cameră preliminară nu este de natură să îi conteste natura sa juridică primară, de act emis de un organ de urmărire penală, ci evocă doar regimul diferit în care se realizează verificarea sa (unul autonom şi nu subsumat mecanismului nulităţii ca în cazul actelor obişnuite de urmărire penală).
} 
În final, subliniem că remediile evocate în hotărârea CJUE pronunțată în cauza ZX ar trebui să opereze doar în contextul limitat apt a le justifica existența. Acestea nu trebuie să devină mecanisme de eludare o obligației procedurale a instanței de judecată de a soluționa cauza. Astfel, reiterăm faptul că, dacă anumite incidente ivite în cursul judecății, precum schimbarea încadrării juridice dată faptei sau excluderea probelor determinante, nu vizează aspectul extern al acuzației, ci reprezintă chiar carențe interne, strâns legate de temeinicia acesteia, instanța este obligată să îşi realizeze în mod complet funcția activată prin sesizare și învestire, urmând a pronunța o soluție de achitare, întrucât probele în acuzare nu întrunesc standardul minim necesar angajării răspunderii penale prevăzut de art. 103 alin. (2) C.proc.pen., dincolo de orice dubiu rezonabil. În aceste condiții, remediile prezentate, indiferent de ordinea de preferință stabilită de către interpret, devin incidente în măsura în care există neclarități sau ambiguități ale acuzației de natură a împiedica exercitarea adecvată a funcției de judecată, nu și atunci când acuzația nu este sprijinită de probe clare, apte a dovedi dincolo de orice dubiu rezonabil vinovăția inculpatului. 